\title{
THE QUALITY OF IOWA CITIZENSHIP
}

\section{By ORA WILLIAMS}

Iowa is marked by a tiny red circle on the calendar that hangs in the workshop of the Master Builder, indicating approval of the first century of a stalwart statehood and a clean place for the century now at dawn; but the diary of the Time-keeper for the family of republics is scribbled all over with the notes that will be pored over through the ages. The Centennial year has high lighted some of these features. The spirit of the jubilee has dominated in the homes, the schools, the churches, the clubs, the newspaper and radio studios. It is all to the good.

Many lessons lighted up by the lamp of experience have come to the attention of this generation. There seems to have been some surprise on finding how short was the probationary period for the state, the ample equipment for statehood when it was attained and the quality of the citizenship from the first and all through the century. The greatness of Iowa is best measured not in terms of bushels and acres and herds and dollars, but by all that enters into good citizenship.

Iowa has had no period of lawlessness and degradation. The Indian law of reprisals for wrongs, one tribe against another, differs not the least from the so-called international law recently invoked by the nations. There was a time of thirteen years when what is now Iowa, occupied chiefly by wandering tribes but open on two sides to all adventurers from fully organized states, was wholly without civil law or orderly government or even the protection of military domination. It is, however, to the credit of the Iowa pioneers that during this time of no-man'sland and the twelve years of territorial probation, order and justice prevailed and human and property rights were respected. 
It was both unusual and important that Iowa came to be, not by way of wise planning by far-seeing statesmen, but because of the irresistable urge of free man for unfettered opportunity in home making. Louisiana, of which Iowa was a part, was acquired as a by-product of European quarrels and not because it was wanted. In the time when Iowa was left without law and to the Indians, fur traders, and lead miners, it was the avowed intent of those who at the national capital were entrusted with authority, to make of this region a territory forever set apart for the use of the native tribes of the north. When the federal government was forced to recognize that the frontier was moving rapidly westward, there was still stubborn opposition to any independent territory west of the Mississippi river at the north. The demand of Iowa pioneers for a separate jurisdiction met determined opposition at.Washington. The rough road to statehood is well known. The obstacles strewn all along the way were overcome by the wisdom, the courage and the enthusiasm of men who had crossed the big river in leaky boats bringing all the necessaries of home making with them. Testimony on this could be secured from a thousand high sources. Justice Horace E. Deemer, of the Iowa supreme court, in an address on the occasion of the anniversary of the state university, put it this way:

The men who created this commonwealth were not consumptives or conscripts. Neither were they criminals nor convicts. They did not come to gamble with the fickle fissures of fortune. As a rule they were not speculators; but they came to cultivate the soil, to establish homes, to found a state with its necessary institutions. They came to stay. And in the composite mind of this courageous body of energetic men and women is to be found the true explanation of all our social and political institutions.

\section{IOWA SOIL ATTRACTED SETTLERS}

There seems to be a close relationship between the quality of the soil and the quality of the citizenry. In Iowa they are certainly closely associated. Men were not attracted to Iowa by the glitter of gold. Lead ore and 
coal are not attractive. But the deep black mould of the forested valleys had a known value. This is what was noted by George Catlin, famous artist, when he painted portraits of Indians in Iowa before territorial days and wrote:

The whole country that we passed over was like a garden, wanting only cultivation, being mostly prairie.

No wonder he declared that it was destined to be "the mint of the country." Lieut. Albert M. Lea, in his notes on the "Iowa district" of Wisconsin territory, described the virgin land in flattering terms, and added:

The character of the population settling on this beautiful country is such as is rarely found in our new territories. With very few exceptions there is not a more orderly, industrious, energetic population west of the Alleghenies than is found in this Iowa District. For intelligence they are not surpassed as a body by any equal number of citizens of any country of the world.

This is testimony contemporaneous with the first arrivals. The eulogies have been printed often, but will always bear repeating. It may be recalled that the convention of citizens held at Burlington, the then capital of Wisconsin territory, in 1837, begged for a law to legalize land titles, saying:

Twenty-five thousand people have settled on lands in Wisconsin territory west of the Mississippi river, in what is called the Iowa district, improved farms, erected buildings, built towns, laid out cities and made valuable improvements, but have not yet been able to secure any kind of title to their homes and farms.

The same convention asked for a separate territory and recited what had happened since the year 1833, four years before:

Settlements were made and crops grown during the same season; and at that early day was the impulse given to the mighty throng of immigration that has subsequently filled our lovely and desirable country with people of intelligence, wealth and enterprise.

The men who had been actual participants in events in that time when Iowa was without law and wholly un- 
governed, save by the sense of justice of the new residents, gave ample testimony to the quality of the people who came to make lowa into a state. Call to the witness stand another whose personal recollection came from very early days, Judge C. C. Nourse, who in his oration on Iowa day at the Centennial Exposition, in Philadelphia, in 1876, said:

Such as we are, the emigration from other states made us. Our free soil, free labor, free schools, free speech, free press, free worship, free men, and free women, were their free gift and contribution. Iowa is the thirty-year-old child of the republic that celebrates the first centennial of its birth. Our state is simply the legitimate offspring of a civilization that has found its highest expression in building up sovereign states. Iowa was not a colony planted by the oppressions of the parent government, and that threw off her allegience as soon as she gained strength to assert her independence; but she was the outgrowth of a natural vitality and enterprise of the nation, begotten in obedience to the divine command to multiply and replenish-born a sovereign by the will and desire of the parent, and baptized at the font of liberty is a voluntary consecration of her political life.

All this that is so much to the credit of Iowa at the beginning has been brought to the light again for refreshment of the Iowa spirit, in many ways, during the Centennial year of statehood. There can be no possible excuse for anyone thinking of Iowa as a reformed rowdyish frontier where the law of the jungle was slowly and painfully extinguished. The home makers who brought their axes and plows, along with their spelling books and bibles, wore stout clothing and kept their faces clean and their hearts pure. One of the first acts of state legislation was to provide for academies and universities, even before a system of common schools could be set going. The first act of the first general assembly looked to protection of the public school fund.

\section{IoWA's HIGH IDEALS OF EQUALITY}

In the literature of the Centennial year it has not been overlooked that one of the elements favorable to development of a virile culture in Iowa was that the rising 
of the state was coincident with the rising of the tide that swept the last vestige of slavery from the western continent. The settlement of the Iowa district and the making of the Iowa state occurred at a time when the American people were getting ready to live up to the high ideals of equality expressed in their constitution. It was in this period when tempers became strained by the bitterness of argument, that a great reformer started a national magazine and placed at its head the declaration:

I am in earnest - I will not equivocate-I will not excuse-I will not retreat a single inch-and I will be heard.

The response to this was a sovereign state of the union offering a reward of $\$ 5,000$ for the arrest and conviction of this presumptious advocate of freedom. In such a tense atmosphere, the makers of Iowa made and won their fight for free soil and a state properly shaped and quite independent. The story of this memorable fight has been told over and over again, with profit and pleasure. It was Iowa that broke the evil design to make the Mississippi river a barrier to the expansion of freedom, and Iowa forced a union with the nation on Iowa terms. This is what Dr. William Salter meant when he said in 1896 at the anniversary of the constitution in Burlington:

Iowa was the child of that union and the 'only child', as Senator Grimes' immortal words expressed it, 'of the Missouri compromise' which was regarded by the patriots of its time as of equal sacredness with the constitution of the Nation.

During the early part of the nineteenth century, when men spoke of the great west they always included Iowa in their thoughts, but they did not add invidious terms as to soil or society. Writers and lecturers came and returned eastward with word of glowing praise. Theodore Tilton felt compelled to advise his friends that he did not paint in too glowing colors his word pictures of the west, and added:

It is a majestic region; its people belong to the nobility of mankind. 
This was much the same thought as that in the mind of Justice Samuel F. Miller, of the United States supreme court, when in his dedication of the Iowa supreme court chambers in June 1886, he said (and it was made of record then by the present writer) that-

The great lawyers of the future are to be reared up in the agricultural regions, and Iowa stands as fair a chance as any other state.

Gov. Samuel J. Kirkwood had been in a position to judge correctly of the quality of Iowa citizenry, and he has been quoted as saying:

We are rearing the typical American, the Western Yankee if you choose to call him so, the man of grit, the man of nerve, the man of broad and liberal views, the man of tolerance of opinion, the man of energy, the man who will some day dominate this empire of ours.

But this is bringing the story down to near the present and peering into the future a little way. The Civil war period, as well as the times of the later wars of world-wide extent, justified the predictions and promises of the early writers and speakers. The conclusion must be that Iowa started out with a fine people located on a rich soil and that there never has been any great variation in the quality of either. Sen. James Harlan, presiding at the historic event of the laying of the corner stone of the State Historical building, forty-seven years ago, said :

There is, I think, no other community of two and a quarter millions of people anywhere on earth, whose masses are so well provided with physical comforts, or possessing more ample opportunities for intellectual, moral and social culture, coupled with the conveniences and even luxuries, which make this epic a marvel in world history, than the people of Iowa.

That was said when Iowa was little more than half as old as it is today, and everyone knows that progress has gone on without abatement. Following the veteran senator, came John A. Kasson, and in his dedication address he said: 
It is not from the bosom of inherited wealth, not from the commercial counting room, nor from the noisy factory or the fiery furnace and rolling mill, that the wise and broad statesmanship, equal to the grandeur of the nation to be served, can be expected to spring. Characters destined to such service require the educational environment of the country, the influences of the tranquil nature, the stimulus of the evening sky, the lessons of patience and foresight taught by the revolving seasons and the patient preparation of the fruitful ground. . . . . It is therefore to be expected that Iowa, in her steady evolution, prepare herself to be the mother of statesmen.

There is no need to dismiss these expressions of flat tering regard for the Iowa of yesterday and high promises for the Iowa of tomorrow, as the chance utterances of fervid orators carried away by enthusiasm of the moment, for the quotations picked at random from hundreds of others readily available to every student of Iowa history, are from the mouths or pens of solid and substantial men who would take no risks for their reputations. In the state's gallery of portraits of men and women of note there are over two hundred likenesses of those whose lives lie like an open book before all who care to know how well the quality of manhood has kept abreast of the productivity of the soil and the shops. Several hundred libraries are filled with the printed stories of how Iowa people have moved steadily along safe lines toward the best community association. The utterances of the prophets and the historians are in fine harmony. The Time-keeper of eternity will not be embarassed by Iowa. 
Copyright of Annals of Iowa is the property of State of Iowa, by \& through the State Historical Society of Iowa and its content may not be copied or emailed to multiple sites or posted to a listserv without the copyright holder's express written permission. However, users may print, download, or email articles for individual use. 